DOI https://doi.org/10.18551/rjoas.2017-01.32

\title{
OVERVIEW ON THE ADDITIVES USED IN IMPROVEMENT OF DOUGH FLOW BEHAVING CHARACTERISTICS
}

\author{
Ghobadi Elnaz, Kaviani Mehdi \\ Ferdowsi University of Mashhad, Mashhad, Iran \\ Khan Muhammad Usman \\ University of Agriculture, Faisalabad, Pakistan \\ Shariati Mohammad Ali \\ All-Russian Research Institute of Phytopathology, Moscow Region, Russia \\ *E-mail: kaviyani.mehdi@yahoo.com
}

\begin{abstract}
Bread in all its diversity has cited as an ancient foodstuff for over 6000 years; bread dough, due to its viscoelastic behavior may consider as the most complicated rheological system which highly effects on final products' sensorial and textural properties. Since the research dough rheology is of being challenging issues, therefore this explains why dough rheology has been an attractive title for several decades. Recently, demand to use new formula and sources such as cassava which result in enhancement of digestibility and along with it, the incorporation of aforesaid sources in cereal products, has been converted to a growingly investigation of rheological properties of dough. Substitution level of any novel sources directly effects on texture properties, even adverse affections, which evaluates by panelists therefore in this review we focus on different concepts of bread rheology and the affection of all added ingredients on physiochemical properties.
\end{abstract}

\section{KEY WORDS}

Food rheology, physiochemical properties, organoleptic properties, sensory evaluation.

Depending on the regions human being is living, a range of cereals consider as the most used one and therefore climatic conditions, growth process and the type of soil even effect on the quality of their products (Taketa et al., 2004). Considering bread as a widely consuming commodities in many nations, the role of additives in technological improving along with concerns related to its quality and sustainability are issues which makes bread so determinative and important in dietetic (Goesaert et al., 2008, Rostami et al., 2013).

Among bakery products, bread is a high demand commodities find in families' food baskets, therefore the possible risks may transmit when distributing this kind of products is of course, a concern for nutritionist. With regards to the fact that enriching is targeting healthier diet (Wood,2002; Izydorczyk et al., 2001), addition of compounds such as $\beta$-glucan, fibers (soluble and insoluble dietary fibers (Hadfield and Bennett, 1998; Meuser et al., 1994; Ghafari et al., 2013; Cummings , 1994) and other cereals flours as well as gums (GómezDíaz and Navaza, 2003) namely alginate, carrageenan etc (Rosell et al., 2001) to the wheat dough is of interest (Straumite et al., 2010; Raninen et al., 2010). Mainly, addition of an ingredient to bread formula is performed with aiming at functions like oil uptake (Albert and Mittal, 2002; Lucca and Tepper, 1994), increase nutritional value, extending shelf life and shelf stability and diminishes the incidence of diseases e.g. gastrointestinal and fibers are of such those compounds (Park et al., 1997; Anderson et al., 2009; Figuerola et al., 2005; Rosell et al., 2001; Gurkin, 2002).

It must be noted that subjecting of compounds to mechanical and heat treatments during baking cause to some changes in additives nature, (Collar and Armero, 1996; Létang et al., 1999; Rosell et al., 2007; Moreira et al., 2010) effecting final product in terms of flavor and rheological properties which is routinely a technical issue (Katina et al.2006). Rheology 
of each fluid or semi fluid food product plays an important role in quality of it (Bloksma, 1990). To produce dough, some ingredients incorporate with each other consisting of water, salt, flour, additives. The role of each ingredient in bread formula can be explained; water as the main liquid of formula plasticize dough and helps to its extension (Belton, 2003). The percent water absorption increased significantly with the addition of surfactants (monodiglyceride and lecithin) alone or in combination. Moreover, the overall dough rheological characteristics and baking quality improved and further these surfactants retarded the rate of staling in bread (Azizi et al., 2003). The role of salt imperceptibly affects via affection of hydrogen bonds and cohesiveness of system (Eliasson and Larsson, 1993). The fact that more salt can bond with more water molecules, it can imply that gluten strength will increase (Preston, 1985; Ghadami et al., 2014). Either main bread base compounds or additives have their priorities and limitations in creating targeted properties.

Dietary fibers. Fibers contain some sub structures including lignin, cellulose, pectin and carbohydrates components (e.g. modified cellulose, derivate fibers from cereals or fruits, inulin and guar) (Elleuch et al., 2011; Sudha et al., 2007; Zhang and Moore, 1997; Gomez et al., 2003; Wang et al., 2002). Psyllium seed is a source of dietary fiber from Plantago genus by its incorporation cholesterol levels are reduced (Cummings, 1993; Anderson et al., 2000).

Non starch polymers such as pentosa (Izydorcszyk et al., 2003) are important owing to its functional properties such as the role of them in cell wall against other harmful microorganisms (Maes and Delcour, 2002).

Another group of hydrocolloids is so-called Gums whose affections are different on dough quality; for instance locust bean gives water holding property and increase softness of dough, or in case of xanthan and alginate hindering some gluten-protein interactions leading to modification in technical properties of dough (Rao et al., 2000).

B-glucan can create high viscous dough (Delcour et al., 1991; Wang et al., 1998; Nikoofar et al., 2013). Some other sources of ingredients and additives can be classed as non-wheat flour (Gandhi et al., 2001 and Sharma and Chauhan, 2002) owing to their dietary fibers. Production of flour can be from grains like wheat, rye, maize \& roots like cassava in order to enrich wheat flour (Spiekermann, 2006; Ekop et al., 2007; Lin et al., 2009).

These additives also give their rheological properties (Oluwole et al., 2006). furthermore, Oyster mushroom, a source of dietary fiber both soluble and insoluble mainly B glucan (Fahmey et al., 1981; Ulloa et al., 1988; Varughese, et al.,1996; Petrovska et al., 2002), therefore increases population public health from the viewpoint of nutritional (Autio et al., 1998). Enriching with amino acids also studied by Stark et al. (1975) and Hoover. (1979).

Reducing and oxidizing agents

Both additives of interchanging and improving s-s bonds affecting on the final strength of dough (Eliasson and Larsson, 1993, Wrigley et al., 1998). Concerning the type and variety of wheat, it must note that their physiological and theological properties can have far reaching influences on the final dough. Improvers, mainly oxidizers and reducers 2,3 , are a group of additives targeting on ehnacing the bread qualities in stages like fermentation, baking and etc.

Proteins. Gluten is rich in gliadins and glutenins. Protein-starch interactions mostly comes from Gluten which is composed of gliadins(prolamines); responsible for plasticity and glutenins (glutelines); responsible for elasticity.

Dynamic rheological parameters of glutens are able to indicate the wheat quality. Glutens from poor quality reconstituted using glutens of different wheat cultivars and a content source of starch and water soluble (Khatkar and Schofield, 2002). Protein effects on increasing of water affection (Hefnawy et al., 2012).

Commonly, the quality and quantity of proteins consider as critical parameter in determining flour quality grade but starch is more important (Lindahl and Eliasson, 1986). Due to unique structure of peptide connected amino acids in polymer chains, they play role in flavor, structure and texture of foodstuffs. Dough is a complex, nonlinear set with time dependent viscoelastic system (Mani et al., 1992). Viscoelastic behavior of dough contains completely viscous liquid and complete elastic solid properties (Lindahl, L., A. C. Elisson, 1992). Primarily, nonfat dry milk powder was added to dough due to as bellows; 
Increase of water uptake capacity in dough, enhancing the body properties of bread dough, consistency and modification of dough, improving bread color as a result of lactose (dry milk contains 52\%) presence in browning reaction, reduction of staling rate.

Enriched lysine materials such as beans are a superior in fortifying bread in developing countries where lack of sufficient wheat source has led to importing this necessity good. Addition of cowpea flour increase the level of water uptake in wheat flour may lead to starch broken up in baking stage (Hallen et al., 2004). Cohesiveness of dough only is just influenced by soybean protein (Marco and Rosell, 2008). Legumes such as soybean and chickpea are active in emulsifying properties and its stability (Tömösközi et al., 2001).

Since dairy proteins such as whey proteins can be used as a protein source in dough. it has been also studied in details e.g. $4 \%$ of sodium caseinate reduce extensibility compared to whey protein concentration which increase this characteristic (Kenny et al., 2001; Rostami et al., 2012). Addition of dairy products also enhances the mouth feel viscoelasticity of dough and overall properties of dough (Ahlborn et al., 2005; Gallagher et al., 2004; Moore et al., 2006; Schober et al., 2005).

Starch. After cellulose, the most occurring carbohydrate is starch which present mostly in endosperm (Kulp, 1972). Starch, due to retrogradiation properties, is the reason of staling in texture. Indeed, the non-crystal part of starch which so called amylose is responsible for staling. Depending on the type of mixing material, some different physiochemical and microbiological phenomenon occur in kneading stage. The process of bread making is started by mixing continued by development stage in which manifestation of elasticity introduced via appearing a smoothly surface due to removing of water from surface.

Humectants. The role of some additives is to ehnace machining properties and texture of breads (Ribotta et al., 2008; Barcenas and Rosell, 2006, 2007; Azizi et al., 2003; Caballero et al., 2007).

Due to hygroscopic properties of humectants such as sorbitol, Glycerin etc, they have the capability of controlling aquatic systems in dough structure.

Fat replacer. The most challenging part of using fat replacer is their possibility embodying dough, mouth feel and other desirable rheological properties.

Fat replacers such as maltodextrins, with no side effects, create lubricant properties of dough (Yackel and Cox, 1992). Polyxdestroe participates in mouth feel and creaminess properties (Mitchell, 1996). Some other fat replacers are inulin and Simplesse effects on modulus of dough. (O'Brien et al., 2003). Fat replacers such as maltodextrins, with no side effects, create lubricant properties of dough (Yackel \& Cox, 1992). Polyxdestroe participates in mouth feel and creaminess properties (Mitchell, 1996).

Enzymes. Enzymes are used in baking to improve dough handling properties and the quality of baked products. Double sulfide cross-linked affecting enzymes like Glucose oxidase are additives to consider far reaching effects in different level of additions on final dough rheological properties; for instance in high levels (Bonet et al., 2006).

\section{CONCLUSION}

Regarding the quality and quantity of each additive it must be noted that a wide range of compounds are available which has to be studied in details from not only the viewpoint of technically but deforming potentials of them. To date, addition of many additives to dough behavior characteristics have studied. But still more studies need to appear the microstructure, macrostructure, interactions even chemical and physical phenomenon.

\section{REFERENCES}

1. Ahlborn, G. J., Pike, O. A., Hendrix, S. B., Hess, W. M., \& Huber, C. S. (2005). Sensory, mechanical, and microscopic evaluation of staling in low-protein and gluten-free breads. Cereal Chemistry, 82, 328-335. http://dx.doi.org/10.1094/CC-82-0328 
2. Anderson, J.W., Baird, P., Davis, R.H., Ferreri, S., Knudtson , M., Koraym, A.,Waters V., \& Williams, C.L. (2009). Health benefits of dietary fiber. Nutrition Reviews, 67, 188-205. http://dx.doi.org/10.1111/j.1753-4887.2009.00189.x.

3. Albert, S., \& Mittal , G.S.(2002). Comparative evaluation of edible coatings to reduce fat uptake in a deep fried cereal product. Food Research International, 35, 445-458. ttp://dx.doi.org/10.1016/s0963-9969(01)00139-9.

4. Atwell, W. A. (2002). Whole-wheat products e an overview. In L. Marquart, J. L. Slavin, \& R. G. Fulcher (Eds.), Whole-grain foods in health and disease. St. Paul, Minnesota: American Association of Cereal Chemists.

5. Anderson, J.W., Allgood, L.D., Lawrence, A., Altringer, L.A., Jerdack, G.R., \& Hengehold, D.A. (2000). Morel J.G., American Journal of Clinical Nutrition, 71, 472-479.

6. Azizi, M.H., N. Rajabzadeh, E., \& Riahi. (2003).Effect of mono-diglyceride and lecithin on dough rheological characteristics and quality of flat bread. LWT-Food Sci. Technol, 36(2):189-193. http://dx.doi.org/10.1016/s0023-6438(02)00201-3.

7. Belton, P.S. (2003). The molecular basis of dough rheology. In: Bread making improving quality. Wood head Publishing. Cambridge, UK. pp. 273- 287.

8. Bloksma, A.H. (1990). Dough structure, dough rheology, and baking quality. Cereal Foods World, 35 (1990), 237-244.

9. Collar, C., \& Armero, E. (1996). Physico-chemical mechanisms of bread staling during storage: Formulateddoughs as a technological issue for improvement of bread functionality and keeping quality. Recent Research Developments in Nutrition, 1, pp. 115-143.ud). Theoretical and Applied Genetics, 108, 1236-1242.

10. Cummings, J.H. (1993). The Effect of Dietary Fiber on Fecal Weight and Composition. In Dietary Fiber in Human Nutrition, SpillerG. A., Ed. 2nd ed., CRC: Boca Raton F.L., 263349. http://dx.doi.org/10.1201/9781420038514.ch4.4.

11. Davidou, S., Le, Meste, M., Debever E., \& Bekaert ,D. (1996). A contribution to the study of staling of white bread: effect of water and hydrocolloid. Food Hydrocolloids, 10, 375383. http://dx.doi.org/10.1016/s0268-005x(96)80016-6.

12. Elleuch, M., Bedigian, D., Roiseux, O., Besbes, S., Blecker, C., \& Attia, H. (2011). Dietary fibre and fibre-rich byproducts of food processing: Characterization, technological functionality and commercial applications: a review. Food Chemistry, 124, 411-421. http://dx.doi.org/10.1016/j.foodchem.2010.06.077.

13. Figuerola, F., Hurtado, M. L., Estevéz, A. M., Chiffelle, I.,\& Asenjo, F. (2005). Fibre concentrates from Apple pomace and citrus peel as potential fibre sources for food enrichment. Food Chemistry, 91, 395-401.

14. Ghadami, M. A., Nasr Esfahani, M., Mirhojjati, S.H. et al (2014). Evaluation of quality indicators related to quality bread wheat promising lines. Russian Journal of Agricultural and Socio-Economic Sciences, 1(25), 8-13.

15. Ghafari, Z., Hojjatoleslamy, M., Shokrani ,R. Shariaty, M.A. (2013). Use of date syrup as a sweetener in non alcoholic beer: sensory and rheological assessment. Journal of Microbiology, Biotechnology and Food Sciences. 3 (2) 182-184.

16. Giovanelli, G. et al (1997). Eff ects of baking temperature on crumb-staling kinetics. Cereal Chemistry, 74, 710-714. http://dx.doi.org/10.1094/cchem.1997.74.6.710.

17. Gómez-Díaz D., \& Navaza J.M.(2003). Comments about rheological effects of food hydrocolloids addition. Food Agriculture and Environment, 1, 98-102.

18. Gomez, M., Ronda, F., Blanco, C., Caballero, P., \& Apesteguia, A. (2003). Effect of dietary fibre on dough rheology and bread quality. European Food Research Technology, 216, 51-56. http://dx.doi.org/10.1177/1082013208089984.

19. Gurkin, S.(2002). Hydrocolloids - Ingredients that add flexibility to tortilla processing. Cereal Foods World, 47, 41-43.

20. Hadfield, K.A., \& Bennett A.B. (1998). Polygalacturonases: many genes in search of function. Plant Physiology, 117, pp. 337-343. http://dx.doi.org/10.1104/pp.117.2.337.

21. Hallen, E., S. Ibanoglu \& P. Ainsworth. (2004). Effect of fermented/germinated cowpea flour addition on the rheological and baking properties of wheat flour. Journal of Food Engineering, 63(2), 177-184. http://dx.doi.org/10.1016/s0260-8774(03)00298-x. 
22. Hefnawy, T.M.H., El-Shourbagy, G.A. \&Ramadan, M.F.(2012). Impact of adding chickpea (Cicerarietinum L.) flour to wheat flour on the rheological properties of toast bread. International Food Research Journal,19(2),:521-525.

23. Karaoglu M. M. (2006). Eff ect of baking procedure and storage on the pasting properties and staling of part-baked and rebaked white pan bread crumb. International food properties, 9, 609-622. http://dx.doi.org/10.1080/10942910600910095.

24. Katina, K., Salmenkallio-Marttila, M., Partanen, R., Forsell, P., \& Autio, K. (2006).Effects of sourdough and enzymes on staling of high-fibre wheat bread. LWT - Food Science and Technology, 39, 479-491. http://dx.doi.org/10.1016/j.Iwt.2005.03.013

25. Khatkar, B.S. \& and Schofield, J.D.(2002). Dynamicrheology of wheat flour dough. II. Assessment of dough strength and bread-making quality. Journal of The science of Food and Agriculture, 82, 823-826. http://dx.doi.org/10.1002/jsfa.1111.

26. Kulp, K. (1972). Physicochemical properties of starches of wheat and flours, cereal chemistry, Vol. 49, P: 697-706. (57)

27. Lindahl, L., \& Eliasson, A. C. (1986). Effects of wheat proteins on the viscoelastic properties of starch gels. Journal of science food agriculture, 37, 1125-1132. (59) http://dx.doi.org/10.1002/jsfa.2740371112.

28. Létang, C., Piau, M., \& Verdier, C. (1999) Characterization of wheat flour-water doughs. Part I, Rheometry and microstructure, Journal of Food Engineering, 41, 121-132. http://dx.doi.org/10.1016/s0260-8774(99)00082-5.

29. Lindahl, L., \& Elisson, A. C. (1992). A comparison of some rheological properties of durum wheat flour dough. Cereal chemistry, 69(1), 30-34.

30. Lucca P.A., \& Tepper B.J. (1994). Fat replacers and the functionality of fat in foods. Trends Food Science Technology, 5, 12-19. http://dx.doi.org/10.1016/09242244(94)90043-4.

31. Marco, C., \& C.M. Rosell. (2008). Functional and rheological properties of protein enriched gluten free composite flours. Journal of Food Engineering, 88(1), :94-103. http://dx.doi.org/10.1016/j.jfoodeng.2008.01.018.

32. Magdić,D., Horvat, D., Drezner, G., Jurković, Z., \& Šimić G. (2006). Image analysis of bread crumb structure in relation to gluten strength of wheat. Poljoprivreda, 12,58-62.

33. Meuser, F., Brümmer, J.M., \& Seibel W. (1995). Bread varieties in Central Europe. Cereal Food World, 39, 222-230. http://dx.doi.org/10.1094/cfw-51-0166

34. Mitchell, H. L. (1996). The role of bulking agent polydextrose in fat replacement. In S. Roller \& S. A. Jones (Eds.), Handbook of fat replacers, 235-248. Boca Raton, FL: CRC Press.

35. Marin, G. and J.P. Montfort. 1996. Molecular rheology and linear viscoelasticity. In: Rheology for polymer melts processing, Elsevier Science. Amsterdam, Netherland.

36. Moreira, R., Chenlo, F., Torres, M.D., \& Prieto, D.M. (2010). Influence of the particle size on the rheological behavior of chestnut flour dough. Journal of Food Engineering, 100, 270-277. http://dx.doi.org/10.1016/j.jfoodeng.2010.04.009.

37. Moore, M.M., Heinbockel, M., Dockery, P., Ulmer, H.M., \& Arendt, E.K. (2006). Network formation in gluten-free bread with application of transgluteminase. Cereal Chemistry, 83(1), 28-36. http://dx.doi.org/10.1094/CC-83-0028.

38. Nikoofar, E, Hojjatoleslamy, M., Shakerian, A., Molavi, H., Shariaty, M.A. (2013). Surveying the Effect of Oat Beta Glucan As a Fat Replacer on Rheological and Physicochemical Characteristics of Non Fat Set Yoghurt. Intl J Farm \& Alli Sci. Vol., 2 (20): 790-796.

39. Rostami,O., Shariaty, M,A., Mousavi Khaneghah, A. (2013). Comparison the Effects of, Modified Ultra Filtered Cheese Whey, Whey Concentrate and Milk powders on the Rheological and Sensory Properties of Dough and Taftoon. Global Journal of Medicinal Plant Research, 1(1), 106-110, 2013

40. Osuji, C.M.(2006). Importance and use of additives in breadmaking. A paper presented at a training workshop on the use of cassava/wheat composite flour and non-bromate additives for making bread and other confectionaries. Held at Michael Okpara University of Agriculture, Umudike. 
41. Park, H., Seib, P. A., \& Chung, O. K. (1997). Fortifying bread with a mixture of wheat fiber and psyllium husk fiber plus three antioxidants. Cereal Chemistry, 74, 207-211. http://dx.doi.org/10.1094/cchem.1997.74.3.207.

42. Prabhasankar, P., Manohar, R. S., \& Gowda, L. R. (2002). Physicochemical and biochemical characterisation of selected wheat cultivars and their correlation to chapati making quality. European Food Research Technology, 214, 131-137. http://dx.doi.org/10.1007/s00217-001-0435-4.

43. Raininen, J., Lappi, J., Mykkänen, H. \& Poutanen, K. (2011). Dietary fiber type reflects physiological functionality: comparison of grain fiber, inulin, and polydextrose. Nutrition Review, 69, 9-21. http://dx.doi.org/10.1111/j.1753-4887.2010.00358.x

44. Rao, V.K., Mulvaney, S.J. \& Dexter, J.E.. (2000). Rheological characterization of long and short mixing flours based on stress-relaxation. Journal of Cereal Science, 31(2),:159171. http://dx.doi.org/10.1006/jcrs.1999.0295.

45. Rosell ,C.M., Rojas, J.A., \& Benedito, C.(2001). Influence of hydrocolloids on dough rheology and bread quality. Food Hydrocolloids, 15, 75-81. http://dx.doi.org/10.1016/s0268-005x(00)00054-0

46. Rostami, O., Shariaty M.A., Mousavi Khaneghah, A. (2013). Comparison the Effects of, Modified Ultra Filtered Cheese Whey, Whey Concentrate and Milk powders on the Rheological and Sensory Properties of Dough and Taftoon Bread. Global Journal of Medicinal Plant Research, 1(1): 106-110.

47. Schiraldi, A., Piazza, L., Brenna, O., \& Vittadini, E. (1996). Structure and properties of bread dough and crumb: calorimetric, rheological and mechanical investigations on the effects produced by hydrocolloids, pentosans and soluble proteins. Journal of Thermal Analysis, 47, 1339-1360.

48. Schober, T. J., Messerschmidt, M., Bean, S. R., Park, S. H., \& Arendt, E. K. (2005). Gluten-free bread from sorghum: quality differences among hybrids. Cereal Chemistry, 82, 394-404. http://dx.doi.org/10.1094/CC-82-0394.

49. Taketa, S., Kikuchi, S., Awayama, T., Yamamoto, S., Ichii, M., \& Kawasaki, S. (2004). Monophyletic origin of naked barley inferred from molecular analyses of a marker closely linked to the naked caryopsis gene .Theor Appl Genet, 108(7), 1236-42.

50. Topping D.L. et al (2001): Short-chain fatty acids and human colonic function: role of resistant starch and non-starch polysaccharides. Physiological Review, 8, 1031-1064.

51. Tavakolipour , H., \& Kalbasi-Ashtari, A. (2006). Influence of gums on dough properties and flat bread quality of two Persian wheat varieties. J. Food Process Eng. 30, 74-87. http://dx.doi.org/10.1111/j.1745-4530.2007.00090.x

52. Tömösközi, S., R. Lásztity, R. Haraszi and O.Baticz. 2001. Isolation and study of the functional properties of pea proteins. Nahrung, 45(6), 399-401. http://dx.doi.org/10.1002/1521-3803(20011001)45:6<399::aid-food399>3.0.co;2-0.

53. Verma, B., Hucl, P., \& Chibbar, R. N. (2008). Phenolic content and antioxidant properties of bran in 51 wheat cultivars. Cereal Chemistry, 85, 544e549.

54. Veraverbeke, W. S., \& Delcour J. A. (2002). Wheat protein composition and properties of wheat glutenin in relation to breadmaking functionality. Critical Reviews in Food Science and Nutrition, 42, 179-208. http://dx.doi.org/10.1080/10408690290825510.

55. Yackel, W. C., \& Cox, C. L. (1992). Application of starch-based fat replacers. Food Technology, 46, 146-148.

56. Wang, L., Miller, R. A., \& Hoseney, R. C. (1998). Effects of (1!3)(1!4)-b-D-glucans of wheat flour on bread making. Cereal Chemistry, 75, 629-633.

57. Wang, J., Rosell, C.M., \& Benedito de Barbera, C. (2002). Effect of the addition of different fibres on wheat dough performance and bread quality. Food Chemistry, 79, 221 226. http://dx.doi.org/10.1016/s0308-8146(02)00135-8.

58. Wrigley, C.W., J.L. Andrews, F. Bekes, P.W. Gras, R.B., Gupta, F. Macritchie \& Skerrit, J.H. (1998).Protein-protein interaction-essential to doughrheology. In: Hamer, R.J. and R.C. Hoseney.Interactions: Keys to Cereal Quality. AmericanAssociation of Cereal Chemists. Minnesota, USA, 17-46. 